\title{
A contribution to avian ectoparasite fauna of Turkey: the reports of feather mites and tick on the Great tit (Parus major L.)
}

\author{
Gökhan EREN ${ }^{1,2}$ (D), Mustafa Açıc1 ${ }^{1}$ (D)
}

${ }^{1}$ Department of Parasitology, Faculty of Veterinary Medicine, Ondokuz Mayıs University, Samsun, Turkey

${ }^{2}$ Corresponding author: gokhaneren54@gmail.com

\author{
Received: 12 July 2021 \\ Accepted: 17 November 2021 \\ Available online: 27 January 2022
}

ASBTRACT: Birds have a symbiotic relationship with many ectoparasite groups such as chewing lice (Mallophaga: Amblycera, Ischnocera), fleas (Siphonaptera), keds (Diptera: Hippoboscidae), mites (Acari: Sarcoptiformes, Trombidiformes) and ticks (Acari: Ixodidae, Argasidae). In fact, this relationship is mainly based on parasitism, but feather mites are mostly classified as commensal ectosymbionts, compared to other parasitic insects and arachnids. This study reports tick and feather mite species detected on a dead specimen of the Great Tit (Parus major L.) that was brought to the Department of Parasitology, Faculty of Veterinary Medicine, Ondokuz Mayıs University, Samsun, Turkey. As a result of the parasitological examination, the tick samples were identified as Ixodes frontalis (Panzer) and feather mites were identified as Analges mucronatus (Buchholz) and Proctophyllodes stylifer (Buchholz). With this study, A. mucronatus and P. stylifer have been reported for the first time from Turkey, and the feather mite fauna of Turkey has reached 42 identified species.

Keywords: Analges mucronatus, Ixodes frontalis, Proctophyllodes stylifer.

Zoobank: http://zoobank.org/6EEF0F27-2B00-47BB-90B6-C0343C01CC6C

\section{INTRODUCTION}

Feather mites (Acari: Astigmata) are obligatory parasitic or commensal ectosymbionts permanently living on birds. These mites are most commonly found in the plumage of their hosts, especially on the wing and tail feathers (Gaud and Atyeo, 1996; Dabert and Mironov, 1999; Proctor, 2003). They are currently classified under two superfamilies (Analgoidea, Pterolichoidea) in the Astigmata (Krantz and Walter, 2009), although experts of $20^{\text {th }}$ century recognized one more superfamily, Freyanoidea (Gaud and Atyeo, 1978, 1996; Mironov, 2019). More than 2500 species have been known to date, and it is estimated that there could be over 16000 feather mite species in the world (Peterson, 1975; Gaud and Atyeo, 1996; Dabert and Mironov, 1999).

Feather mites have developed various specialized morphological adaptations, depending on hosts and attachment regions. Usually, these mites are classified into four morpho-ecological groups according to their general adaptations and locations on hosts: wing and tail feather mites, contour feather mites, quill mites and skin mites (Mironov, 1987, 1999; Dabert and Mironov, 1999).

The relationship between feather mites and host birds is thought to be a phenomenon between commensalism and parasitism. Some authors consider these organisms to be commensal creatures that feed on oil and feather debris secreted from the uropygial gland (Peterson, 1975; OConnor, 1982; Gaud and Atyeo, 1996). However, in the study conducted by Blanco et al. (2001) showed that the nutrient contents of the intestines of Pterodectes rutilus (Robin) (Proctophyllodidae) and Scutulanyssus nuntiaeveris (Berlese) (Pteronyssidae) included algae, fungi and pollen apparently also taken from the feather surfaces. In addition, as in other symbiotic relationships, feather mites, especially representatives of the family Epidermoptidae, may exert a possible pressure on the immune system due to stress and direct damage of the skin surface (Esch et al., 1975).

Contrary to the feather mite studies in the world, the studied are insufficient from Turkey (Bakırcı and Güleğen, 2005; Aksin, 2007, 2010, 2011; Gürler et al., 2013; Per and Aktaş, 2018; Eren et al., 2021). In these studies, 40 idendified, 2 unidentified feather mites were reported from birds (Table 1). Feather mites are mostly ignored in the field of Veterinary Parasitology from Turkey, as they do not usually cause general condition disorders or infections in domestic and wild birds, unlike other parasitic mites.

Ticks (Acari: Ixodida) have been studied more in avian ectoparasites because of their long distance transportation by birds and their ability to overcome geographical barriers, and also they are vectors for many viral, bacterial and parasitic agents of medical and veterinary importance (Hasle, 2013; Brinkerhoff et al., 2019). As in the world, many studies have been carried out about tick infestation on birds from Turkey (Table 2). In these studies; Amblyomma, Argas, Dermacentor, Haemaphysalis, Hyalomma, Ixodes, Ornithodoros and Rhipicephalus infestations were detected (Kurtınar, 1954; Merdivenci, 1970; Oğuz et al., 2015; Keskin and Erciyas-Yavuz, 2016, 2019; Keskin et al., 2017).

The great tit (Parus major L.) is a passerine bird species distributed in the western Palearctic region in areas suitable for its habitat such as deciduous or mixed woodlands, gardens, parks, shrublands and sometimes coniferous forests (Beaman and Madge, 2010). 
Table 1. List of feather mite species detected so far in Turkey.

\begin{tabular}{|c|c|c|}
\hline Family & Species & References \\
\hline Alloptidae & Alloptoides aythinae & Gürler et al. (2013) \\
\hline Analgidae & $\begin{array}{l}\text { Analges mucronatus*, A. passerinus, A. spiniger, A. turdinus, } \\
\text { Diplaegidia columbae, Megninia ginglymura, Strelkovi- } \\
\text { acarus quadratus }\end{array}$ & $\begin{array}{l}\text { Aksin (2011); Gürler et al. } \\
\text { (2013); Per and Aktaş (2018); } \\
\text { *present study }\end{array}$ \\
\hline Avenzoariidae & Avenzoaria totani & Gürler et al. (2013) \\
\hline Dermoglyphidae & Dermoglyphus sp. & Aksin (2010) \\
\hline Falculiferidae & Falculifer rostratus & Bakırcı and Güleğen (2005) \\
\hline Freyanidae & Freyana anatina, Freyana nyrocae & $\begin{array}{l}\text { Aksin (2007); Gürler et al. } \\
\text { (2013) }\end{array}$ \\
\hline Proctophyllodidae & $\begin{array}{l}\text { Dolichodectes edwardsi, Joubertophyllodes modularis, } \\
\text { Monojoubertia microphylla, Proctophyllodes cetti, P. } \\
\text { clavatus, P. doleophyes, P. lusciniae, P. mesocaulus, P. rube- } \\
\text { culinus, P. scolopacinus, P. stylifer*, P. sylviae, P. troncatus, } \\
\text { Proctophyllodes sp. }\end{array}$ & $\begin{array}{l}\text { Gürler et al. (2013); Per and } \\
\text { Aktaş (2018); *present study }\end{array}$ \\
\hline Pterolichidae & $\begin{array}{l}\text { Grallolichus minutus, Pelargodacna heteromorpha, Periexo- } \\
\text { caulus anacanthus, Pseudolichus solutocurtus, Xoloptes } \\
\text { claudicans }\end{array}$ & $\begin{array}{l}\text { Aksin, 2011; Gürler et al. } \\
\text { (2013); Eren et al. (2021) }\end{array}$ \\
\hline Pteronyssidae & Pteronyssoides striatus, Scutulanyssus hirundicola & Gürler et al. (2013) \\
\hline Ptiloxenidae & Ptiloxenus major & Aksin (2010) \\
\hline Psoroptoididae & Temnalges mesalgoides & Gürler et al. (2013) \\
\hline Trouessartiidae & $\begin{array}{l}\text { Trouessartia bifurcata, T. inexpectata, T. jedliczkai, } T . \\
\text { kratochvili, T. microcaudata, T. reguli, T. rubecula, } T . \\
\text { trouessarti }\end{array}$ & $\begin{array}{l}\text { Gürler et al. (2013); Per and } \\
\text { Aktaș (2018) }\end{array}$ \\
\hline
\end{tabular}

Table 2. List of tick species detected so far on birds from Turkey

\begin{tabular}{|c|c|c|}
\hline \multicolumn{2}{|c|}{ Tick species } & References \\
\hline \multirow{6}{*}{ 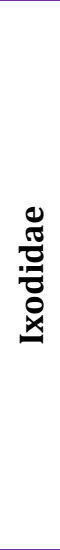 } & Amblyomma sp. & Keskin and Erciyas-Yavuz (2016) \\
\hline & Dermacentor marginatus & Keskin and Erciyas-Yavuz (2016) \\
\hline & $\begin{array}{l}\text { Haemaphysalis concinna, } H . \text { punctata, } H . \text { parva, } H . \\
\text { sulcata, Haemaphysalis sp. }\end{array}$ & $\begin{array}{l}\text { Merdivenci (1970); Leblebicioglu et al. (2014); } \\
\text { Keskin and Erciyas-Yavuz (2016, 2019); Dik and } \\
\text { Kandir (2021) }\end{array}$ \\
\hline & Hyalomma marginatum, Hyalomma sp. & $\begin{array}{l}\text { Merdivenci (1970); Leblebicioglu et al. (2014); } \\
\text { Keskin and Erciyas-Yavuz, (2016, 2019); Dik and } \\
\text { Kandir (2021) }\end{array}$ \\
\hline & $\begin{array}{l}\text { Ixodes arboricola, I. eldaricus, I. festai, I. frontalis*, I. } \\
\text { hexagonus, I. redikorzevi, I. ricinus, Ixodes sp. }\end{array}$ & $\begin{array}{l}\text { Merdivenci (1970); Leblebicioglu et al. (2014); } \\
\text { Keskin et al. (2014); Keskin and Erciyas-Yavuz } \\
\text { (2016, 2019; Dik and Kandir (2021); *present } \\
\text { study }\end{array}$ \\
\hline & Rhipicephalus bursa, R. turanicus & Leblebicioglu et al. (2014); Oğuz et al. (2015) \\
\hline \multirow{2}{*}{ 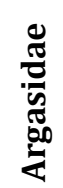 } & Argas persicus, A. reflexus & $\begin{array}{l}\text { Kurtınar (1954); Parrish (1961); Merdivenci } \\
\text { (1970) }\end{array}$ \\
\hline & Ornithodoros coniceps & Merdivenci (1970) \\
\hline
\end{tabular}

Turkey has a rich ornithofauna due to geographically different habitats and being on many migration routes, but ectoparasite studies in birds are unfortunately insufficient. We believe that this study will contribute to the literature on feather mites and tick infestations on birds from Turkey.

\section{MATERIALS AND METHODS}

The specimen of the Great Tit, Parus major L. (Passeriformes: Paridae), found dead at the tram stop in the university campus $\left(41^{\circ} 22^{\prime} 01.3^{\prime \prime} \mathrm{N} \quad 36^{\circ} 11^{\prime} 35.6^{\prime \prime E}\right)$, was brought to the Department of Parasitology Laboratory, 

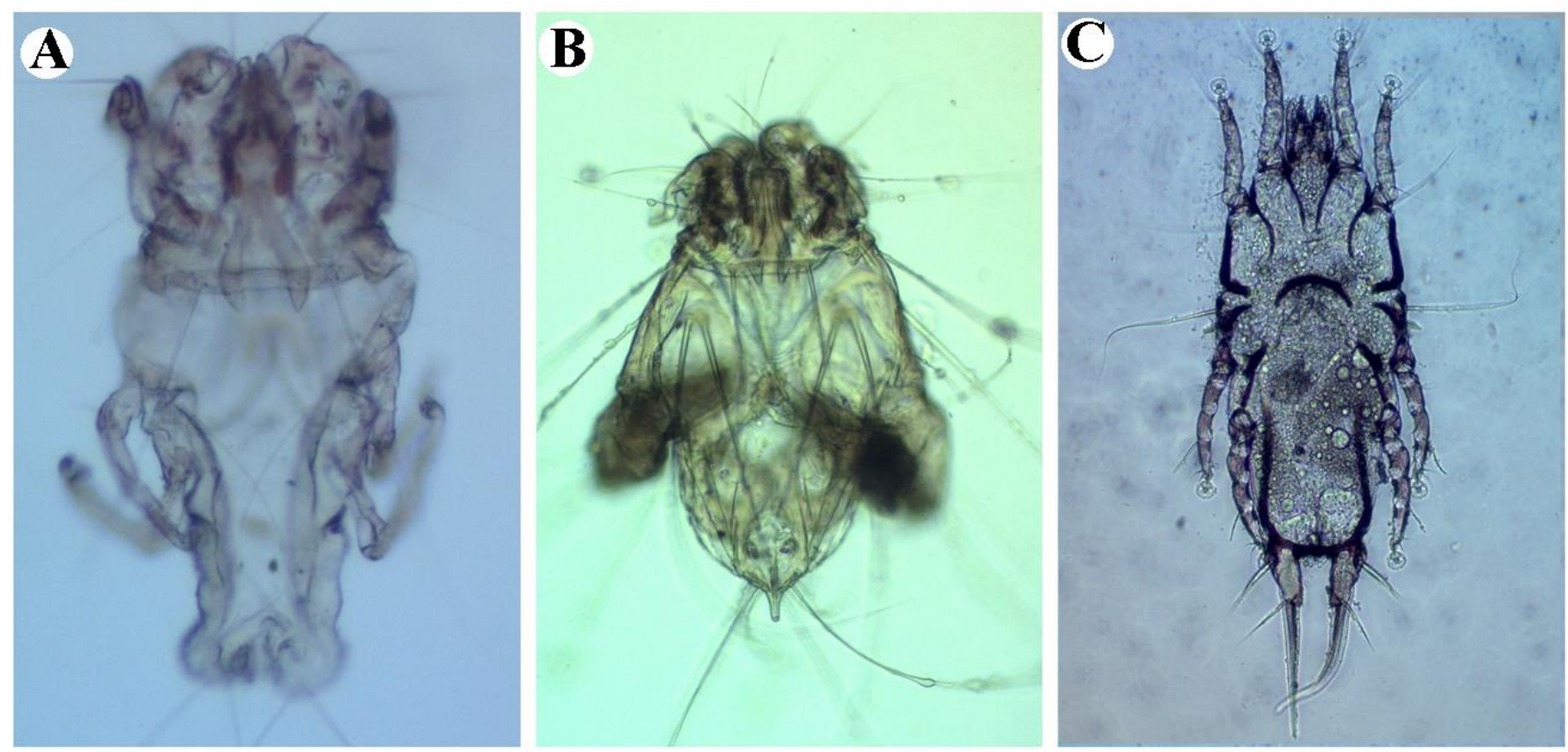

Figure 1. A. Analges mucronatus (female), B. Analges mucronatus (male), C. Proctophyllodes stylifer (female).

Faculty of Veterinary Medicine, Ondokuz Mayıs University (Samsun, Turkey) for parasitological examination. In the process of parasitological examination, samples of mites and ticks were collected by using point tip tweezers and placed in vials with $70 \%$ ethanol. Then, feather mite specimens were cleaned and softened for 24 hours with lactophenol and mounted in slides with Hoyer's medium (Evans, 1992). The tick sample was cleared for 48 hours in lactophenol, and mounted in slides with Canada Balsam. Subsequently, the samples were identified under a light microscope (Nikon Eclipse 80i, Nikon, Tokyo, Japan) using the taxonomic works on corresponding mite taxa with diagnostic keys (Atyeo and Braasch, 1966; Mironov, 1985; Pfäffle et al., 2017). The photographs of the ectoparasites were taken with a camera (Mshot Mdx4-t, Guangzhou, China) integrated with the microscope (Figs 1, 2). The collected mite and tick of samples are preserved in $70 \%$ ethanol in the parasitology laboratory (Karatepe and Karatepe, 2015).

\section{RESULTS}

As a result of microscopic examination, the following ectoparasites have been identified: the hard tick Ixodes frontalis (Panzer, 1795) (1 larva) and feather mites $\mathrm{An}$ alges mucronatus (Buchholz, 1969) (1 male and 1 female) and Proctophyllodes stylifer (Buchholz, 1869) (1 female) were identified.

Analges mucronatus (male and female). The size of idiosoma (length $\times$ width) in male is $290 \times 195 \mu \mathrm{m}$, and in female is $340 \times 160 \mu \mathrm{m}$. Among species the genus Analges (Analgidae: Analginae) this species can be unmistakably identified based on a unique structure of terminal lamella in males, which is modified in a finger-like process with the tip curved ventrally (Fig. 1B).

Proctophyllodes stylifer (female). The size of idiosoma: length $360 \mu \mathrm{m}$, width $164 \mu \mathrm{m}$. Among species of the genus Proctophyllodes (Proctophyllodidae: Proctophyllodinae) associated with European passerines, females of this species can be readily identified in having strongly contrasting sclerotization of the hysteronotal shield, which is almost colourless in most part but with wide dark-brown bands along lateral margins (Fig. 1C).

Ixodes frontalis (larva). Numbers of setae on the scutal, alloscutal and ventral of body are as follows, on both sides: scutal (Sc), 5; central dorsal (Cd), 6; marginal dorsal (Md), 8; supplementary (S), 5; sternal (St), 3; preanal (Pa), 3; premarginal $(\mathrm{Pm}), 5$; marginal ventral $(\mathrm{Mv}), 5$. The scutum is longer than its width, and the idiosomal setae are also quite long. The hypostome is pointed and the dental formula of hypostome are arranged as 3/3 (Fig. $2 \mathrm{~B})$; base of the hypostome with two lateral protrusions. Numbers of setae and spurs on coxae I-III are 2-1-1, respectively (Fig. 2A).

\section{DISCUSSION}

Few studies have been conducted on feather mites in Turkey, and so far 40 identified, two unidentified species of feather mites have been identified in these studies (Bakırcı and Güleğen, 2005; Aksin, 2007, 2010, 2011; Gürler et al., 2013; Per and Aktaș, 2018; Eren et al., 2021). Analges mucronatus (Buchholz, 1869). The genus Analges (Analgidae: Analginae) is the most species-rich in this family with 64 species described so far (Mironov, 2019). Mites of this genus are characterized by the weakly sclerotized body and a number of macrosetae found on both the dorsal and ventral body surfaces, as for most analgides, and also spine-like ventral extensions in the tibiae and tarsi of the first two pairs of legs (Gaud and Atyeo, 1996). Although, Analges species are predominantly distributed on members of the order Passeriformes also known as songbirds. A total of five species have been recorded from birds of other orders, each from a single host from Apodiformes, Columbiformes, Cuculiformes, Piciformes and Psittaciformes; all these host associations are considered questionable and probably were results of 

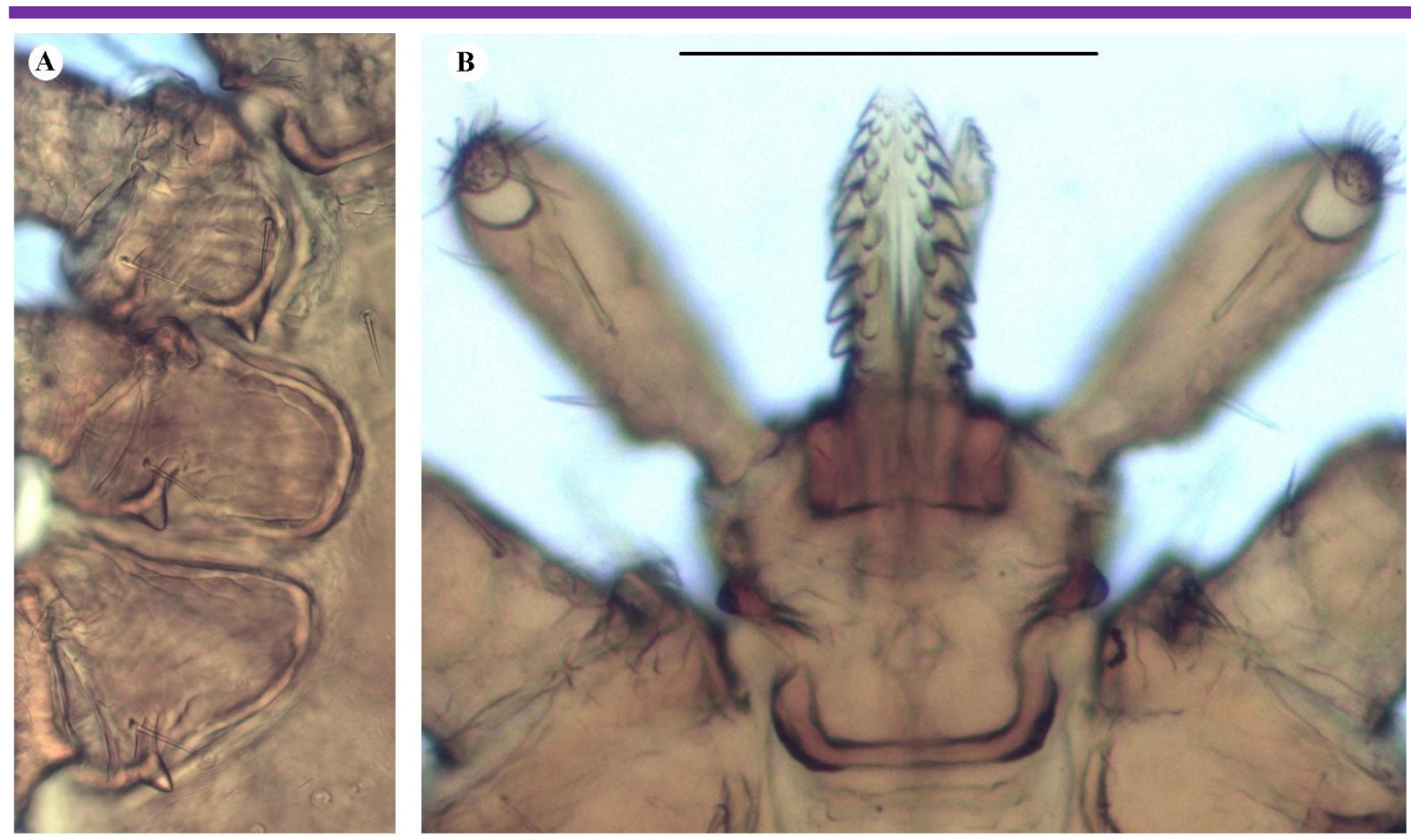

Figure 2. Ixodes frontalis (larva), A. Coxae; B. Ventral of capitulum. Scale bar: $150 \mu \mathrm{m}$.

contamination (Mironov, 2019). The genus Analges is one of most complicate genera of feather mites, because its taxonomy and species identification are based almost exclusively on heteromorphic males (Dabert et al., 2018; Mironov, 2019). Analges mucronatus was first described from the Blue Tit (Cyanistes caeruleus L.) in Germaly (Buchholz, 1869); further it was reported from this host and from Parus major across Western Palearctic (Mironov, 1985, 1996). In Turkey, three Analges species were previously known (Table 1). Analges mucronatus is reported for the first time in this country.

Proctophyllodes stylifer (Buchholz, 1969). The genus Proctophyllodes (Proctophyllodidae: Proctophyllodinae) is the richest among all feather mites with over 150 presently known species classified into 12 species groups (Atyeo and Braasch, 1966; Mironov, 2012; Klimov et al., 2017). In this genus, taxonomy and identification of species are mainly based on male individuals (with the terminal lamellae and genital area as the most important diagnostic characters). Although most members of the genus inhabit birds of the order Passeriformes, several Proctophyllodes species are specific to particular hosts from the orders Apodiformes, Charadriiformes, and Piciformes. Proctophyllodes stylifer has been reported so far from various titmice species in Western Palearctic: the Blue Tit $(C$. caeruleus L.), Great Tit (P. major), Marsh Tit (Poecile palustris L.) and Willow Tit (Poecile montanus Conrad von Baldenstein) (Atyeo and Braasch, 1966; Behnke et al., 1985; Mironov 1996; 2012). In Turkey, nine Proctophyllodes species have been previously reported (Table 1). With the present study, P. stylifer is reported from this country for the first time.
Ticks, which are obligate blood-sucking arthropods, transmit many bacterial, viral and protozoal agents while feeding on hosts. In addition, birds with a good body condition score, sometimes known as tick-related syndrome, cause acute depressive disorder or death characterized by mild or moderate haemorrhage and oedema in the head and neck area where the tick is attached (Monks et al., 2006). Ixodes frontalis, which has a three-host life cycle, is a species that needs birds at every life stage (larva, nymph and adult). It can be easily distinguished from other larva of Ixodes species by looking at its morphological features, especially with dorsal and ventral chaetotaxy and two lateral protrusions in the base of the hypostome. It is known that some hard ticks have been identified using larval chaetotaxy (Clifford and Anastos, 1960). It often causes infestation in members of the order Passeriformes, but it can also cause infestations in members of the Anseriformes, Falconiformes, Galliformes, Gruiformes, and Strigiformes (Pfäffle et al., 2017). Although known specifically as a bird parasite, it has sometimes been reported in mammals such as badgers and martens (Hillyard, 1996) and also humans (Keskin et al., 2017). In the studies conducted so far in Turkey, I. frontalis has been reported from 23 different bird species: Blackbird (Turdus merula L.), Black-headed Warbler (Sylvia atricapilla L.), Black Redstart (Phoenicurus ochruros Gmelin), Bluethroat (Luscinia svecica L.), Cetti's Warbler (Cettia cetti Temminck), Common Chiffchaff (Phylloscopus collybita Vieillot), Dunnock (Prunella modularis L.), Eurasian Penduline Tit (Remiz pendulinus L.), Eurasian Reed Warbler (Acrocephalus scirpaceus Hermann), Eurasian woodcock (Scolopax rusticola L.), Eurasian wren (Troglodytes troglodytes L.), Goldcrest (Regulus regulus L.), Great Reed Warbler (A. arundinaceus L.), Great Tit (P. major L.), Finch (Fringilla coelebs L.), House Sparrow (Passer domesticus 
L.), Robin (Erithacus rubecula L.), Red-breasted Flycatcher (Ficedula parva Bechstein), Sardinian Warbler (S. melanocephala G.), Savi's Warbler (Locustella luscinioides Savi), Song Thrush (Turdus philomelos Brehm), Thrush Nightingale (Luscinia luscinia L.), and Willow Warbler (Phylloscopus trochilus L.) (Keskin and Erciyas-Yavuz, 2016, 2019).

Although Turkey has a rich ornithofauna, which increases day by day and approaching 500 species, parasitological studies on birds are poorly conducted. Including this study so far, about 50 hosts, which are almost $10 \%$ of the ornithofauna of Turkey, have been studied and 42 identified, two unidentified species of mites have been identified (Table 1). In addition, a total of 18 species of infestation have been reported in tick-focused studies (Table 2). In the near future, multidisciplinary studies including ornithology, veterinary parasitology and acarology will contribute to the diversity and distribution of Turkey's feather mite and tick fauna, as well as other parasitic arthropods such as chewing lice, fleas, keds and parasitic mites.

\section{Authors' contributions}

Gökhan Eren: Conceptualization, methodology, resources, visualization, writing - original draft, writing review \& editing. Mustafa Açıcı: Conceptualization, methodology, resources, supervision, visualization, writing - original draft, writing - review \& editing.

\section{Statement of ethics approval}

Ethics approval is not required for the study material consists of parasite specimens collected from a bird found as dead at the tram stop.

\section{Funding}

This study was not supported or not studied granting by any foundation.

\section{Conflict of interest}

The authors declared that there is no conflict of interest.

\section{Acknowledgements}

The authors are grateful to Dr. Sergey V. Mironov (Zoological Institute of the Russian Academy of Sciences, St. Petersburg, Russia) who supported the identification of the feather mites and article review process.

\section{REFERENCES}

Aksin, N. 2007. Freyana anatina (Koch, 1844) feather mites (Acarina, Freyanoidea) recorded for the first time on wild ducks (Subfamily, Anatinae) in Turkey. Türkiye Parazitoloji Dergisi, 31 (4): 302-305.

Aksin, N. 2010. Chewing lice and feather mites on wild partridges. The Indian Veterinary Journal, 87: 940941.
Aksin, N. 2011. Feather mites (Acari: Astigmata) on wild quail (Coturnix coturnix). Indian Veterinary Journal, 88 (4): 69 .

Atyeo, W.T. and Braasch, N.L. 1966. The feather mite genus Proctophyllodes (Sarcoptiformes: Proctopbyllodidae). Bulletin of the University of Nebraska State Museum, 5: 1-354.

Bakırcı, S. and Güleğen, E. 2005. Bir güvercinde tüy akarı (Falculifer rostratus, Buchholz, 1869) olgusu. 14. Ulusal Parazitoloji Kongresi, 25-27 Eylül 2005, İzmir, Turkey, 217. [In Turkish]

Beaman, M. and Madge, S. 2010. The handbook of bird identification: for Europe and the western Palearctic. A\&C Black Publishers, p.715, London, U.K, 868 pp.

Behnke, J.M., McGregor, P.K., Shepherd, M., Wiles, R., Barnard, C., Gilbert, F.S. and Hurst, J.L. 1995. Identity, prevalence and intensity of infestation with wing feather mites on birds (Passeriformes) from the Setubal Peninsula of Portugal. Experimental and Applied Acarology, 19 (8): 443-458. doi: 10.1007/BF00048263

Blanco, G., Tella, J.L., Potti, J. and Baz, A. 2001. Feather mites on birds: costs of parasitism or conditional outcomes?. Journal of Avian Biology, 32 (3): 271-274. doi: 10.1111/j.0908-8857.2001.320310.x.

Bursali, A., Keskin, A. and Tekin, S. 2012. A review of the ticks (Acari: Ixodida) of Turkey: species diversity, hosts and geographical distribution. Experimental and Applied Acarology, 57 (1): 91-104. doi: 10.1007/s10493-012-9530-4

Brinkerhoff, R.J., Dang, L., Streby, H.M. and Gimpel, M. 2019. Life history characteristics of birds influence patterns of tick parasitism. Infection Ecology and Epidemiology, 9 (1): 1547096. doi: $10.1080 / 20008686.2018 .1547096$

Clifford, C.M. and Anastos, G. 1960. The use of chaetotaxy in the identification of larval ticks (Acarina: Ixodidae). The Journal of Parasitology, 46 (5): 567-578.

Dabert. J. and Mironov, S.V. 1999. Origin and evolution of feather mites (Astigmata). Experimental and Applied Acarology, 23: 437-454. doi: 10.1023/A:1006180705101

Dabert, M., Solarczyk, P., Badek, A. and Dabert, J. 2004. Taxonomic status of the oligoxenous feather mite species: are we dealing with species in statu nascendi? Phytophaga, 14: 425-431.

Dabert, J., Mironov, S.V. and Janiga, M. 2018. Two new species of the feather mite genus Analges Nitzsch, 1818 (Analgoidea: Analgidae) from accentors (Passeriformes: Prunellidae)-morphological descriptions with DNA barcode data. Systematic and Applied Acarology, 23 (12): 2288-2303.

doi: $10.11158 /$ saa.23.12.2 
Dik, B. and Kandir, E.H. 2021. Ectoparasites in Some Wild Birds (Aves) in Turkey. Progress in Nutrition, 23, e2021261.

doi: 10.23751/pn.v23iS2.11919

Eren, G., Açıcı, M., Özkoç, Ö.Ü. and Gürler, A.T. 2021. First record of Pelargodacna heteromorpha Perez \& Atyeo, 1992 (Pterolichidae, Xoloptopidinae) on a black stork (Ciconia nigra) from Turkey. Eduvet International Veterinary Science Congress, 25-27 June 2021, Turkey, 292-293.

Esch, G.W., Gibbons, J.W. and Bourque, J.E. 1975. An analysis of the relationship between stress and parasitism. The American Midland Naturalist, 93: 339-353.

Evans, G.0. 1992. Principles of Acarology. CAB International, Wallingford, United Kingdom, 563 pp.

Gaud, J. and Atyeo W.T. 1978. Nouvelles superfamilles pour les Acariens astigmates parasites d'oiseaux. Acarologia, 19: 678-685. [In French]

Gaud, J. and Atyeo, W.T. 1996. Feather mites of the world (Acarina, Astigmata): The supraspecific taxa (Part I). Annales du Musée Royal de l'Afrique Centrale, Sciences Zoologiques, Belgium.

Gürler, A.T., Mironov, S.V. and Erciyes-Yavuz, K. 2013. Avian feather mites (Acari: Astigmata) of Samsun, Turkey. Acarologia, 53 (1): 17-23.

doi: 10.1051/acarologia/20132078

Hasle, G. 2013. Transport of ixodid ticks and tick-borne pathogens by migratory birds. Frontiers in Cellular and Infection Microbiology, 3 (48): 1-6.

doi: 10.3389/fcimb.2013.00048

Karatepe, B. and Karatepe, M. 2015. Arthropodlarin toplanması ve muhafaza yöntemleri, In: Arthropodoloji. Karaer, K.Z. and Dumanl, N. (Ed.). Medisan Yayın Serisi, Ankara, Turkey, 81: 309-319. [In Turkish]

Keskin, A., Koprulu, T.K., Bursali, A., Ozsemir, A.C., Yavuz, K.E. and Tekin, S. 2014. First record of Ixodes arboricola (Ixodida: Ixodidae) from Turkey with presence of Candidatus Rickettsia vini (Rickettsiales: Rickettsiaceae). Journal of Medical Entomology, 51 (4): 864-867. doi:10.1603/ME13169

Keskin, A. and Erciyas-Yavuz, K. 2016. A preliminary investigation on ticks (Acari: Ixodidae) infesting birds in Kızllırmak Delta, Turkey. Journal of Medical Entomology, 53 (1): 217-220.

doi: 10.1093/jme/tjv149

Keskin, A., Bulut, Y.E., Keskin, A. and Bursalı, A. 2017. Tick attachment sites in humans living in the Tokat province of Turkey. Türk Hijyen ve Deneysel Biyoloji Dergisi, 74 (2): 121-128. doi: 10.5505/TurkHijyen.2017.24993

Keskin, A. and Erciyas-Yavuz, K. 2019. Ticks (Acari: Ixodidae) parasitizing passerine birds in Turkey with new records and new tick-host associations. Journal of Medical Entomology, 56 (1): 156-161.

doi: 10.1093/jme/tjy151

Klimov P.B, Mironov, S.V. and OConnor, B.M. 2017. Convergent and unidirectional evolution of extremely long aedeagi in the largest feather mite genus, Proctophyllodes (Acari: Proctophyllodidae): evidence from comparative molecular and morphological phylogenetics. Molecular Phylogenetics and Evolution, 114: 212-224. doi: 10.1016/j.ympev.2017.06.008

Kurtpınar, H. 1954. Türkiye Keneleri (Ixodoidea): Morfoloji, biyoloji, konakçı yayılışları ve medikal önemleri. Güven Matbaası, Ankara, Turkey, 102 pp. [In Turkish]

Krantz, G.W. and Walter, D.E. 2009. A manual of acarology. 3rd edition. Texas Tech University Press, Lubbock, USA, 807 pp.

Leblebicioglu, H., Eroglu, C., Erciyas-Yavuz, K., Hokelek, M., Acici, M. and Yilmaz, H. (2014). Role of migratory birds in spreading Crimean-Congo hemorrhagic fever, Turkey. Emerging Infectious Diseases, 20 (8): 1331-1334. doi: 10.3201/eid2008.131547

Merdivenci, A. 1970. Türkiye parazitleri ve parazitolojik yayınları. İstanbul Üniversitesi, Cerrahpaşa Tıp Fakültesi Yayınları, Kutulmuş Matbaası, İstanbul, Turkey, 324 pp. [In Turkish]

Mironov, S.V. 1985. Feather mites of the genera Analges and Pteronyssoides from the European part of the USSR (Sarcoptiformes, Analgoidea). Parazitologicheskii Sbornik, 33: 159-208. [In Russian]

Mironov, S.V. 1987. Morphological adaptations of feather mites to different types of plumage and skin of birds. Parazitologicheskii Sbornik, 34: 114-132. [In Russian]

Mironov, S.V. 1996. Feather mites of the passerines in the North-West of Russia. Parazitologiya, 30 (6): 521-539. [In Russian]

Mironov, S.V. 1999. Feather mites: general morphological adaptations, phylogeny and coevolutionary relationships with birds. Ekologija (Vilnius, Lithuania), 2: 57 66.

Mironov, S.V. 2012. New species of the feather mite genus Proctophyllodes Robin, 1877 (Acari: Analgoidea: Proctophyllodidae) from European passerines (Aves: Passeriformes), with an updated checklist of the genus. Acarina, 20 (2): 130-158.

Mironov, S.V. 2019. A new species of the feather mite genus Analges Nitzsch, 1818 (Acariformes: Analgidae) from the streaked spiderhunter Arachnothera magna (Passeriformes: Nectariniidae), with a renewed diagnosis and world checklist to the genus. Acarina, 27 (1): 19-43.

doi: 10.21684/0132-8077-2019-27-1-19-43 
Monks, D., Fisher, M. and Forbes, N.A. 2006. Ixodes frontalis and avian tick-related syndrome in the United Kingdom. Journal of Small Animal Practice, 47 (8): 451-455.

doi: 10.1111/j.1748-5827.2006.00031.x

OConnor, B.M. 1982. Evolutionary ecology of astigmatid mites. Annual Review of Entomology, 27: 385-409.

Oğuz, B., Değer, S., Özdal, N., Biçek, K., Kılınç, Ö.O. and Aslan, L. 2015. The first case of Rhipicephalus turanicus from red hawk (Buteo rufinus) in Van. Van Veterinary Journal, 26 (1): 39-41.

Per, E. and Aktaş, M. 2018. The monitoring of feather mites (Acari, Astigmata) of the Warbler (Aves: Sylviidae) species in the Kizılırmak delta, Samsun, Turkey. Turkish Journal of Zoology, 42 (4): 394-401. doi: 10.3906/zoo-1711-12
Peterson, P.C. 1975. An analysis of host-parasite associations among feather mites (Acari: Analgoidea). Miscellaneous Publications of the Entomological Society of America, 9: 237-242.

Pfäffle, M.P., Madder, M., Santos-Silva, M.M. and Petney, T.N. 2017. Ixodes frontalis (Panzer, 1798). In: Ticks of Europe and North Africa: A Guide to Species Identification. Estrada-Peña, A., Mihalca, A.D., and Petney, T.N. (Eds). Springer, Cham, Switzerland, 91-96.

Proctor, H.C. 2003. Feather mites (Acari: Astigmata): ecology, behavior and evolution. Annual Review of Entomology, 48: 185-209.

doi: 10.1146/annurev.ento.48.091801.112725

Edited by: Salih Doğan

Reviewed by: Three anonymous referees

Citation: Eren, G. and Açıcı, M. 2022. A contribution to avian ectoparasite fauna of Turkey: the reports of feather mites and tick on the Great tit (Parus major L.). Acarological Studies, 4 (1): 21-27. 